\title{
Turning sunlight into stone: the oxalate-carbonate pathway in a tropical tree ecosystem
}

\author{
G. Cailleau ${ }^{1}$, O. Braissant ${ }^{2}$, and E. P. Verrecchia ${ }^{1}$ \\ ${ }^{1}$ Institute of geology and palaeontology, University of Lausanne, Lausanne, Switzerland \\ ${ }^{2}$ Laboratory of Biomechanics \& Biocalorimetry, Biozentrum/Pharmazentrum, University of Basel, Basel, Switzerland
}

Received: 11 November 2010 - Published in Biogeosciences Discuss.: 7 February 2011

Revised: 22 June 2011 - Accepted: 23 June 2011 - Published: 5 July 2011

\begin{abstract}
An African oxalogenic tree, the iroko tree (Milicia excelsa), has the property to enhance carbonate precipitation in tropical oxisols, where such accumulations are not expected due to the acidic conditions in these types of soils. This uncommon process is linked to the oxalate-carbonate pathway, which increases soil $\mathrm{pH}$ through oxalate oxidation. In order to investigate the oxalate-carbonate pathway in the iroko system, fluxes of matter have been identified, described, and evaluated from field to microscopic scales. In the first centimeters of the soil profile, decaying of the organic matter allows the release of whewellite crystals, mainly due to the action of termites and saprophytic fungi. In addition, a concomitant flux of carbonate formed in wood tissues contributes to the carbonate flux and is identified as a direct consequence of wood feeding by termites. Nevertheless, calcite biomineralization of the tree is not a consequence of in situ oxalate consumption, but rather related to the oxalate oxidation inside the upper part of the soil. The consequence of this oxidation is the presence of carbonate ions in the soil solution pumped through the roots, leading to preferential mineralization of the roots and the trunk base. An ideal scenario for the iroko biomineralization and soil carbonate accumulation starts with oxalatization: as the iroko tree grows, the organic matter flux to the soil constitutes the litter, and an oxalate pool is formed on the forest ground. Then, wood rotting agents (mainly termites, saprophytic fungi, and bacteria) release significant amounts of oxalate crystals from decaying plant tissues. In addition, some of these agents are themselves producers of oxalate (e.g. fungi). Both processes contribute to a soil pool of "available" oxalate crystals. Oxalate consumption by oxalotrophic bacteria can then start. Car-
\end{abstract}

Correspondence to: G. Cailleau (guillaume.cailleau@unil.ch) bonate and calcium ions present in the soil solution represent the end products of the oxalate-carbonate pathway. The solution is pumped through the roots, leading to carbonate precipitation. The main pools of carbon are clearly identified as the organic matter (the tree and its organic products), the oxalate crystals, and the various carbonate features. A functional model based on field observations and diagenetic investigations with $\delta^{13} \mathrm{C}$ signatures of the various compartments involved in the local carbon cycle is proposed. It suggests that the iroko ecosystem can act as a long-term carbon sink, as long as the calcium source is related to non-carbonate rocks. Consequently, this carbon sink, driven by the oxalate carbonate pathway around an iroko tree, constitutes a true carbon trapping ecosystem as defined by ecological theory.

\section{Introduction}

Biomineralization in the Plant kingdom resulting in the presence of oxalate and/or carbonate crystals has been known for a long time (Leidy, 1883; Record, 1927; Campbell and Fisher, 1932; Harris 1933; Pobeguin, 1943, 1954; Carozzi, 1967; Franceschi and Horner, 1980). Three types of biomineralization have been observed in the iroko tree (Milicia excelsa, Moraceae) among the numerous ones described in the natural environment: oxalatization, calcitization, and silicification (Braissant et al., 2004; Cailleau et al., 2005). In an area originally expected to be carbonate-free near Daloa (Ivory Coast), calcium carbonate accumulations have been described in soils (although originally acidic), as well as in iroko tree tissues. The photosynthetic process which leads to calcium oxalate accumulation in plant tissues has been well studied (Franceschi and Nakata, 2005). In addition, the fact that the carbon source of oxalates is the atmospheric

Published by Copernicus Publications on behalf of the European Geosciences Union. 
$\mathrm{CO}_{2}$ and the calcium originates from calcium carbonate-free sources (silicates from parent rock and dust) makes this system a potential carbon sink (Cailleau et al., 2004, Verrecchia et al., 2006). Nevertheless, the way by which calcium carbonate accumulates in these soils and plant tissues in relationship with the oxalate-carbonate transformation (Braissant et al., 2004) still needs to be thoroughly documented. Is this mechanism only functional in the presence of oxalate (supplied by an oxalogenic tree) and soil oxalotrophic bacteria, as observed in vitro, or do other key players need to be involved to make this system an efficient carbon sink? Consequently, the aim of this study is to document and challenge our present-day knowledge about the oxalate-carbonate pathway involved in tropical settings. For this purpose, we used microscopic and petrographic investigations, as well as stable carbon isotope measurements on various phases, to test the previously hypothesized model elaborated from experimental data obtained in the laboratory and described by Braissant et al. (2004).

\section{State of the art}

\subsection{Oxalate, Ca cycle and the oxalate-carbonate pathway}

Various pathways may produce oxalic acid during plant metabolism (Franceschi and Nakata, 2005). Oxalic acid as a chelator of $\mathrm{Ca}$ leads to the accumulation of $\mathrm{Ca}$-oxalate in plant tissues and is observed in all organs and tissues from roots to leaves. Various roles have been attributed to calcium oxalate (see Franceschi and Nakata, 2005 for a review), from calcium regulation (Robert and Roland, 1989) and mechanical support, to protection from grazing (Schneider, 1901). These crystals are present in the cell vacuole in various shapes, ranging from bipyramids to needles.

The calcium cycle involving oxalate precipitation by saprophytic fungi and its further oxidation during bacterial metabolism has been documented in a coniferous temperate forest (Cromack et al., 1977). This cycle, resulting in carbonate precipitation, has also been described as a diagenetic process leading to the cementation of powdery limestones in semi-arid environments (Verrecchia, 1990; Verrecchia et al., 1991; Gadd, 1999). The oxalate oxidation is known to increase the $\mathrm{pH}$ (Jayasuriya, 1955) as the oxalate, a relatively strong acid, is transformed into a weaker acid (i.e. carbonic acid). This consumption of oxalate has been experimentally described and reproduced by Braissant et al. $(2002,2004)$ using oxalotrophic bacteria isolated from the soil surrounding M. excelsa. During experiments, the medium can reach a $\mathrm{pH}>9$, well over the stability $\mathrm{pH}$ for calcite ( 8.4 in surface conditions of temperature and pressure), although starting from an initial experimental $\mathrm{pH}$ of 6.5 .

\subsection{Calcium carbonate in the iroko and its surrounding soil}

Calcium carbonate mineralization of $M$. excelsa has been observed since Campbell and Fisher (1932) and Harris (1933) mentioned carbonate "stones" on trunks in relationship with sap bleedings due to injuries on sapwood tissues. Wounds were caused by various factors such as wind, fire, and mammals (including humans). Remains of insects (e.g. Cerambycid larvae) were often observed nestled in the wound supposedly allowed the sap to bleed for a long period of time (Harris, 1933). These observations were completed by Carozzi (1967) who described large calcite-cemented sandstones generated by large sap bleedings in the vicinity of severely wounded lower trunk portions and roots. Recently, these carbonate accumulations were defined within the context of the Ivory Coast sites as a carbon sink (Cailleau et al., 2004). The NT (Near Threatened) conservation status attributed to the iroko tree puts in peril its associated C sink within the range of the calculated $\mathrm{C}$ sequestration.

\section{Materials and methods}

\subsection{Geographical settings}

At the Biga (Ivory Coast; $6^{\circ} 39^{\circ} \mathrm{N}, 6^{\circ} 23^{\prime} \mathrm{W}$ ) and Mankaré (Cameroon; $5^{\circ} 27^{\prime} \mathrm{N}, 11^{\circ} 03^{\prime} \mathrm{E}$ ) sites, several carbonate blocks (ca. $10 \mathrm{~cm} \times 10 \mathrm{~cm} \times 10 \mathrm{~cm}$; their nature determined using $10 \%$ hydrochloric acid) were taken from a soil profile close to a hollow stump of a recently felled iroko (still present on the site). Various organic wood fragments (including bark) were sampled on the stump, the roots above the ground, as well as in the soil itself. Bulk samples were taken in the soil horizons at different depths for further micro-sampling in the laboratory using a binocular microscope. Exudates of sap and samples of carbonate related to wounds were collected from the trunk of a younger iroko tree at less than five hundred meters from the investigated profiles. At the Kani site (Ivory Coast; $8^{\circ} 28^{\prime \circ} \mathrm{N}, 6^{\circ} 36^{\prime} \mathrm{W}$ ), wood slabs originating from wood feeder infestation (likely termites) were sampled from a stump as well as various fragments of roots, and carbonate concretions associated with sap bleedings. Some other Cameroon sites such as Massangam $\left(5^{\circ} 25^{\prime} \mathrm{N}, 10^{\circ} 59^{\prime} \mathrm{E}\right)$, Machatoum $\left(5^{\circ} 27^{\prime} \mathrm{N}, 11^{\circ} 03^{\prime} \mathrm{E}\right)$, and Mambicham $\left(5^{\circ} 49^{\prime} \mathrm{N}, 11^{\circ} 13^{\prime} \mathrm{E}\right)$ were also explored for additional observations and analyses.

At the Biga site, the mean annual temperature (MAT) is $24.5^{\circ} \mathrm{C}$ and the mean annual rainfall (MAR) is $1500 \mathrm{~mm} \mathrm{yr}^{-1}$. Five dry months occur in this semi-deciduous forest belonging to the Guinean domain. At the Kani site, the MAT is estimated as equal to the Biga site, MAR is $1300 \mathrm{~mm} \mathrm{yr}^{-1}$ and there is a 6-month dry period occurring in this gallery forest belonging to the Sudanian domain. In the Massangam area (including the Massangam, Machatoum, 
and Mankare sites), the MAT is $23^{\circ} \mathrm{C}$ and the MAR is $1800 \mathrm{~mm} \mathrm{yr}^{-1}$. These sites are located in the gallery forest belonging to the Guinean domain. The studied soils mainly belong to the reference soil group Ferralsol (WRB 2007).

\subsection{Laboratory methods}

Various kinds of carbonate features were separated with tweezers in the laboratory. In addition, a density separation using a bromoform gradient was performed on the sap containing organic wood fragments, as well as crystals (Walton et al., 2003). Two bromoform solutions were used because different components were expected to be present in the sap after observation on a glass plate under binocular microscope. Bromoform solutions of $1500 \mathrm{~kg} \mathrm{~m}^{-3}$ and $2900 \mathrm{~kg} \mathrm{~m}^{-3}$ were prepared in acetone in order to separate carbonate (mass density $2700 \mathrm{~kg} \mathrm{~m}^{-3}$ ), from any possible oxalate (mass density 2020 to $2300 \mathrm{~kg} \mathrm{~m}^{-3}$ for the most common species, i.e. weddellite and whewellite), and iroko wood fragments (mass density 450 to $1100 \mathrm{~kg} \mathrm{~m}^{-3}$ ) or denser material (mostly silicates). At the bottom of a $50 \mathrm{~mL}$ tube, $20 \mathrm{~mL}$ of the most dense solution was poured out and the second solution was added with caution in order to form a sharp interface boundary. Sap was then poured in the tube and centrifuged. The various materials present in the sample fractionated in function of their density. By this method, it was possible to extract carbonate and expected oxalate material at the interface between the bromoform solutions and the remaining low density material in the upper part of the tube.

Carbonate blocks (of various sizes, from $250 \mathrm{~cm}^{3}$ to several $\mathrm{dm}^{3}$ ) and wood fragments were embedded in a twocomponent epoxy resin in order to make thin sections. These $35 \mu \mathrm{m}$ thick thin sections were polished using a $1 \mu \mathrm{m}$ diamond powder suspended in solution. Optical observations were performed using a Leitz Aristoplan microscope equipped with a X100 oil-immersion lens. Plane-polarized light (PPL), cross-polarized light (XPL), and UV fluorescence light observations were conducted on thin sections including various materials, i.e. stones, wood, bark, soil horizons, and concretions. Some features were observed using a Phillips XL30 Field Emission Gun Scanning Electron Microscope (FEG-SEM), either in the conventional (SEM) or low temperature mode (LTSEM). X-ray diffraction analyses were performed using a Scintag diffractometer.

Wood fragments were crushed after immersion in liquid nitrogen in order to concentrate the oxalate content from three wood samples. After this step, the powder was poured into a $1 \mathrm{M} \mathrm{HCl}$ solution overnight under agitation (Clausen et al., 2008). Then, the $\mathrm{pH}$ was adjusted to 2 for $48 \mathrm{~h}$ by adding $6 \mathrm{M} \mathrm{HCl}$, thus allowing complete dissolution of oxalate in the solution. Samples were filtered using a Nalgene $0.2 \mathrm{~mm}$ syringe. A solution of a high concentration of $\mathrm{Ca}^{2+}$ ions was added to the filtrate, which contains oxalic acid in order to precipitate Ca-oxalate crystals. SEM observations (for crystal habits) as well as X-ray diffraction analyses confirmed their oxalate nature. The carbon isotopic signature of oxalate crystals has been performed on this extracted material at the Federal Institute of Technology in Zurich (Hofmann and Bernasconi, 1998). This method does not induce any bias in the carbon isotopic ratio as the carbon bonds are preserved and do not undergo any fractionation. Therefore, this method is a good way to obtain the oxalate ion for further ${ }^{13} \mathrm{C}$ isotopic studies. At the Machatoum site, it was possible, using a chainsaw, to sample a $49 \mathrm{~cm}$-long blade of iroko wood representing a ray of the stem, which was later dated using ${ }^{14} \mathrm{C}$. Organic carbon isotopic signatures for tree tissues (including ${ }^{13} \mathrm{C}$ and ${ }^{14} \mathrm{C}$ ) were performed at the Radiocarbon Laboratory, Physics Institute, University of Bern (Switzerland). The main isotopic investigation was conducted at the Biga site. Additional measurements were made at other sites in order to get a picture of the variability in this type of system. The carbon isotopic signatures of carbonates $\left({ }^{13} \mathrm{C}\right)$ were measured using a VG Micromass 602 mass spectrometer at the University Pierre and Marie Curie in Paris (France). The $\delta^{13} \mathrm{C}$ values are given relative to the V-PDB standard (\%o). The analytical error is $0.2 \%$ V-PDB, and when the number of samples $n \geq 3$, the standard deviation is given.

\section{Results}

\subsection{Field observations}

Most of the studied trees have a trunk $>1 \mathrm{~m}$ wide at breast height. They present large bark flakes (Fig. 1a). Many bark slabs resulting from bark delamination are found on the ground near the trunk. Bark fragments without wounds never react with hydrochloric acid, reflecting the absence of calcite. Some secretions are also observed directly on the trunk surface (Fig. 1b; Campbell and Fisher, 1932). They are related to insects (other than termites). These secretions finally harden and form carbonate concretions. The presence of wood feeders/borers (e.g. termites) has also been observed, often leading to the formation of a hollow trunk (approximately $50 \%$ of the trees observed during the reconnaissance work presented traces of insect infestations).

Slabs of wood tissue associated with termite borings have also been observed (Fig. 1c, d) inside hollow trunks or lying on the soil beneath. Sometimes these wood slabs react with hydrochloric acid, indicating the presence of carbonate. Nevertheless, this reaction is common but restricted to small areas (such as spots on wood fragments). A lot of small fragments are observed in the first thirty centimetres of soil developed below an hollow trunk. These fragments have been determined as wood in origin due to their morphology. They are highly reactive to hydrochloric acid. In addition, these fragments have been identified as carbonate pseudomorphoses on wood cells using a binocular microscope. 

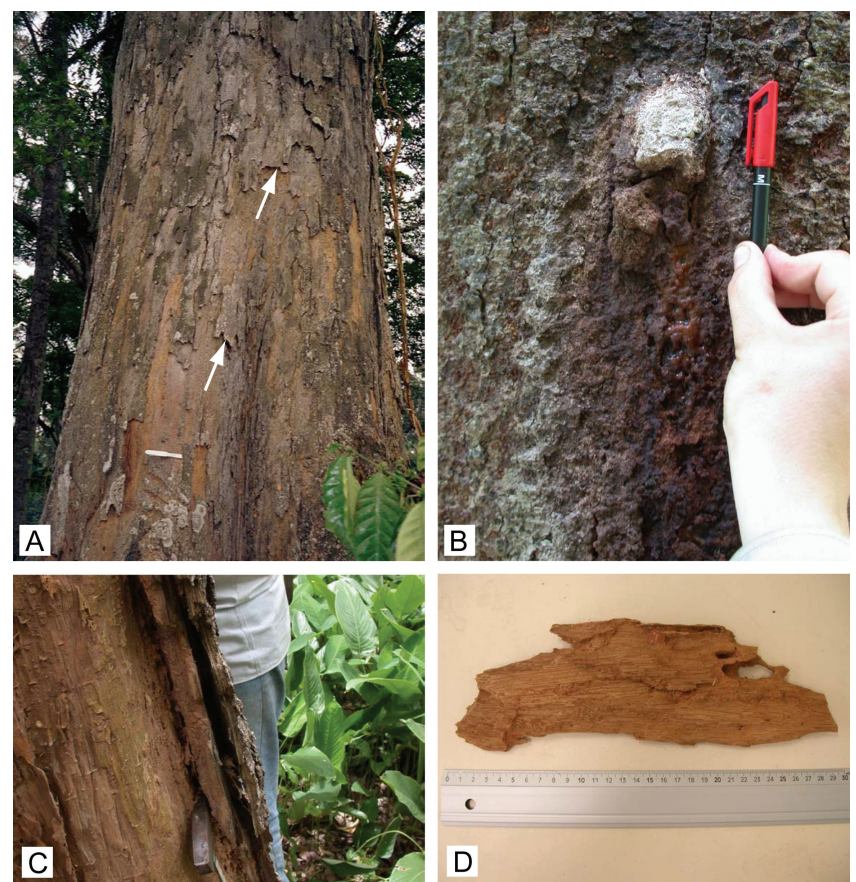

Fig. 1. (a) An iroko trunk showing abundant bark "flakes" (white arrows) on its trunk (site of Mambicham, Cameroon). This is typical for mature trees. (b) Carbonate associated with sap exudation observed at the Kani site (Ivory Coast). Unidentified live insects have been observed in the liquid secretion after removal of the hardened secretion. (c) Xylem tissues exposed to the atmosphere due to termite activity (Kani site). (d) Wood slab partially reacting to hydrochloric acid found on the ground inside a hollow trunk at the Biga site.

\subsection{X-ray diffraction analyses}

X-ray diffraction analyses were performed on bark and wood tissues (Fig. 2). There is a distinct difference between bark tissues, mainly embedding whewellite (calcium oxalate monohydrate) and amorphous silica, and wood tissues, in which whewellite and calcium carbonate have been detected. Some large blocks of carbonate, interpreted as former roots (Cailleau et al., 2005), have also been identified as pure calcite, which is consistent with their chemical composition (97 to $99 \%$ of $\mathrm{CaCO}_{3}$ ).

\subsection{Optical observations}

Oxalate crystals - In the bark, oxalate crystals are present in parenchyma cells. There is no evidence of dissolution of these crystals. The amorphous silica phase has been observed in parenchyma cells and phloem rays surrounding oxalate crystals (Fig. 3a). The amorphous silica phase is more present in the areas where phloem rays are numerous and closely grouped compared to where they are sparse. In the wood tissues, whewellite crystals have been observed in the cells surrounding the conductive vessels, in the xylem rays

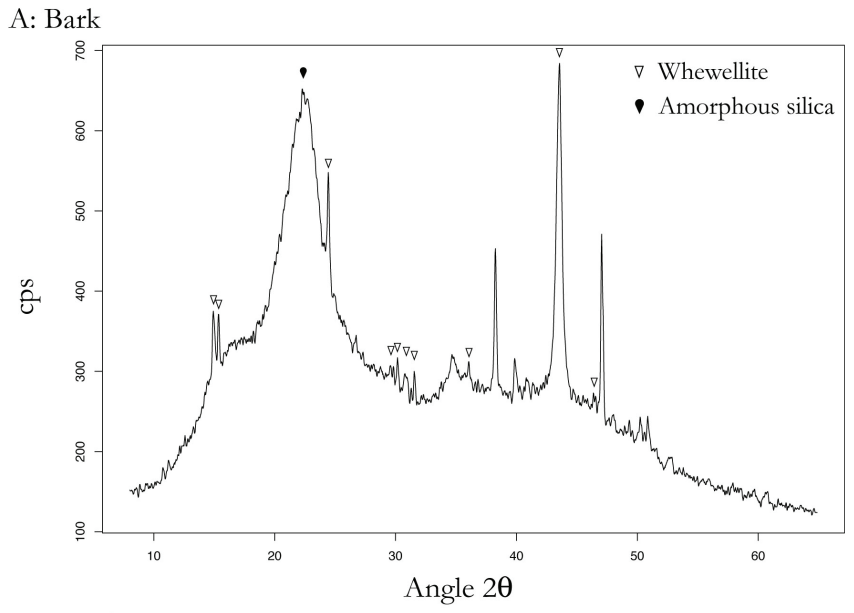

B: Wood

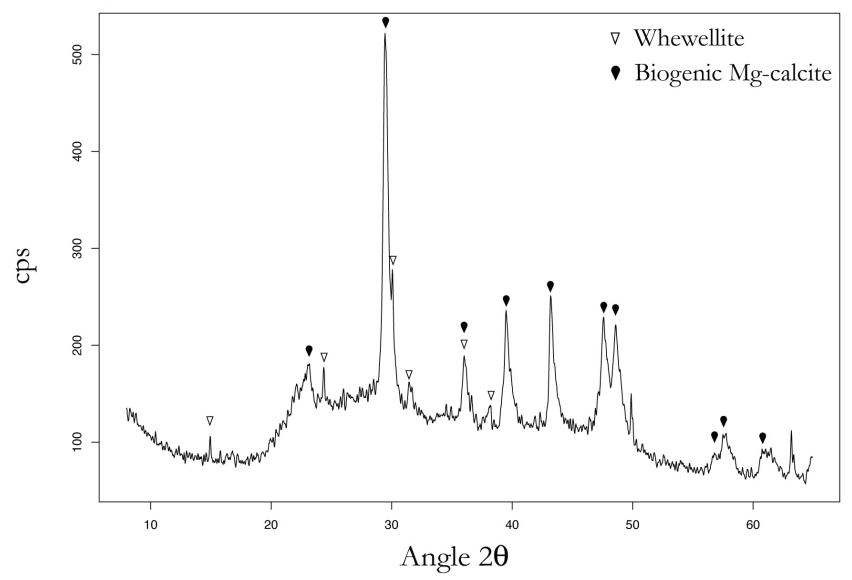

Fig. 2. (a) X-ray diffractogram of a partially mineralized iroko bark showing the presence of whewellite (calcium oxalate monohydrate) and amorphous silica. (b) X-ray diffractogram of partially mineralized iroko wood tissues showing the presence of whewellite (calcium oxalate monohydrate) and biogenic Mg-calcite (High Magnesium Calcite). cps: counts per second; Angle 2 $\theta$ : Bragg angle, angle between the incident and diffracted X-ray beams.

(Fig. 3b), but are scarce in parenchyma cells. In all the thin sections of wood fragments, oxalate crystals do not show any traces of dissolution. However, an exception has been observed (Fig. 3c) in wood tissues exposed to the atmosphere and originating from wounds on the trunk (Fig. 3d). The dissolved whewellite crystals are close to the edge of the wound. In this case, a front of calcitization is clearly visible advancing from the outer part of the trunk to its inner part (Fig. 3d). The release of undamaged oxalate crystals is observed in fragments of rotting wood tissues (Fig. 3e) in the soil surrounding the iroko. Some oxalate crystals have been observed free in soil pores. Their prismatic habit is characteristic of whewellite. 

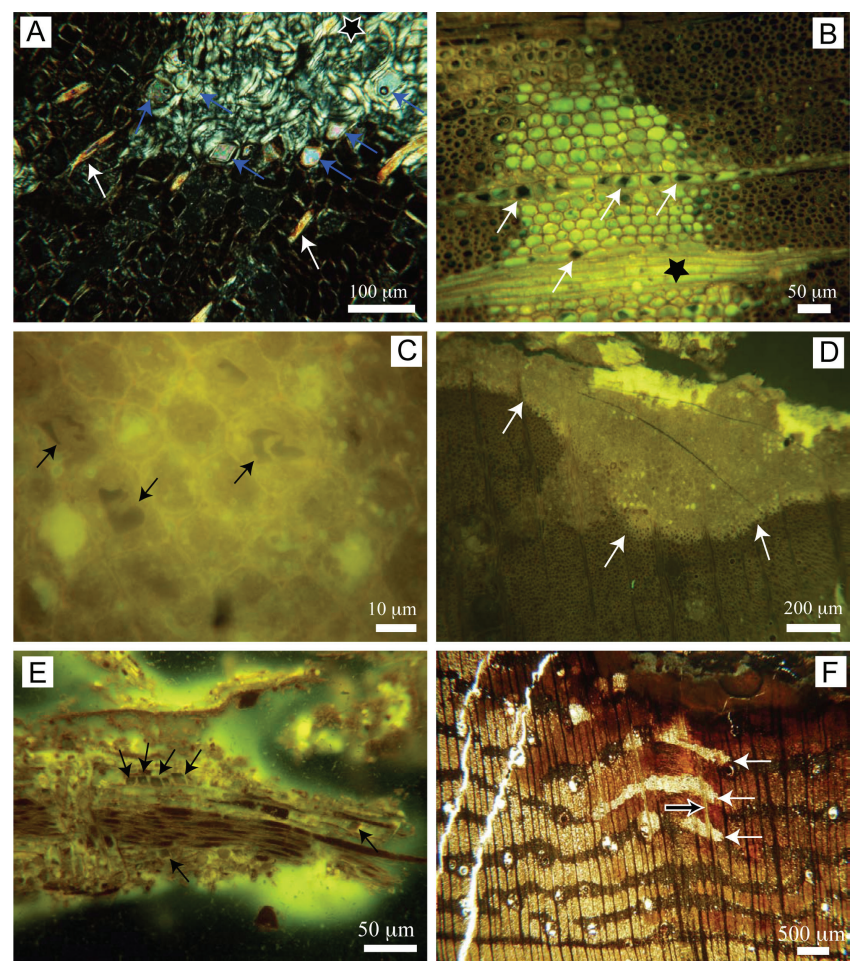

Fig. 3. (a) Optical cross-polarized light microscope observations. Bark tissues showing a silicification front (bright area, black star) developed among the parenchyma cells. Oxalate crystals (blue arrows) are embedded in the amorphous silica, which postdates the oxalatization. White arrows: phloem rays. (b-e) optical microscope observations under UV epifluorescence. (b) In the wood tissues, oxalate crystals (white arrows, dark shapes) are found in xylem rays (elongated structures). No oxalate crystal dissolution features have been observed. A calcitization phase is present (black star) in xylem rays and lateral cells of conductive vessels (the brighter area). Carbonate mineralization postdates the precipitation of oxalate. (c) Thin section of wood tissues sampled close to a wound. Oxalate crystals show dissolution traits (black arrows). (d) Calcitization front (white arrows) close to a wound; open atmosphere is on the top righthand corner. In this particular case, dissolution features on oxalate crystals can be observed (see Fig. 3c). (e) Thin section of a decaying wood fragment shortly before release of oxalate crystals (black arrows). This sample is located in the first few centimetres of a soil profile. (f) Optical plane polarized light microscope observation of wood tissues showing calcitized area (white arrows). Both xylem rays and conductive vessels are calcitized. The black arrow shows the calcitized xylem rays.

Carbonate phase - In wood tissues, a carbonate phase has also been observed in the xylem rays, as well as in conductive vessels and parenchyma cells (Fig. 3f). Calcite is frequently observed surrounding undamaged oxalate crystals. In the soil, fabrics of former wood are observed, but these features are crumbly and made of macroscopic calcitic rods (calcite pseudomorphoses on wood fibers) associated with calcitic infillings of conductive vessels.

\subsection{SEM observations}

\subsubsection{Oxalate crystals}

Decayed wood fragments sampled in the soil close to the trunk are associated with concentrations of released crystals. These prismatic to rhombohedral euhedral habits are typical of whewellite. Moreover, sub-aerial root samples from Kani show the same kind of oxalate crystal release in the soil medium which, in this case, is clearly related to termite activity. The relative concentration of these crystals increases with wood tissue decay (Fig. 4a). Oxalate crystals from soil samples are also observed free in soil pores (Cailleau et al., 2005) and some of them exhibit dissolution features (Fig. 4b).

\subsubsection{Carbonate phases}

Many pseudomorphoses have been observed below the hollow trunk. They appear either as a whole wood fabric (Fig. 4c) or as disseminated features such as cellulose fibres, parenchyma cells, and conductive vessels. These features are the three most abundant in the soil (Cailleau et al., 2005). The mineral material, selectively separated from sap, is constituted by various features: euhedral calcitic rhombohedron, micritic aggregates (Braissant et al., 2004; Cailleau et al., 2005), calcite pseudomorphoses on cellulose fibers, and parenchyma cells (Fig. 4d).

\subsection{Carbon isotope signatures (Table 1)}

\subsubsection{C isotope signatures of organic matter and calcium oxalates}

${ }^{14} \mathrm{C}$ dating for the Machatoum tree gives an age of $170 \pm 30$ yrs old. As the Machatoum and Biga trees have similar trunk diameters, we assume that their ages are in the same range. This age is about double the first estimate based on information by locals, who knew the tree to be at least $80 y r$ old (Cailleau et al., 2004). Six samples of wood tissues (five from the same tree - an iroko from Machatoum and one from Biga) were analyzed in order to determine the organic matter $\delta^{13} \mathrm{C}$ signature. The iroko trees from Biga and Machatoum have a $\delta^{13} \mathrm{C}$ signature of $-24.0(n=1)$ and $-26.3 \pm 1.1 \%$ o $(n=5)$ respectively. According to Cerling et al. (1997) or Diefendorf et al. (2010), these values are in the range of variability of $\mathrm{C} 3$ plants.

$\delta^{13} \mathrm{C}$ signatures of the Ca-oxalate were measured on various samples from different sites. Oxalate extracted from the bark of iroko trees from Biga and Mankaré has a $\delta^{13} \mathrm{C}=-19.0 \%$ o $(n=1)$ and $\delta^{13} \mathrm{C}=-17.2 \%$ o $(n=$ 1), respectively. Oxalate from iroko roots from Kani has a $\delta^{13} \mathrm{C}=-19.8 \%(n=1)$. The mean value is ${ }^{13} \mathrm{C}=-18.7 \pm 1.3 \%$ or these oxalates $(n=3)$. In Biga, the difference between oxalate and bulk wood tissues is $5 \%$. When considering all the sites, the difference reaches 
Table 1. C isotope signatures from both carbonate and organic matter (Ivory Coast and Cameroon samples). CIC sample names refer to Biga site samples.

\begin{tabular}{|c|c|c|c|}
\hline Sample name & $\delta^{13} \mathrm{C}$ & Depth (m) & Sample type \\
\hline CIC 001 & -11.1 & 0.2 & $\mathrm{CaCO}_{3}$ Block, mostly composed of micritic textures \\
\hline CIC 002 & -5.4 & 0.4 & $\mathrm{CaCO}_{3}$ Block, mostly composed of micritic textures \\
\hline CIC 016 & -10.4 & 0 & $\mathrm{CaCO}_{3}$ Block \\
\hline CIC 017 & -6.9 & 0 & $\mathrm{CaCO}_{3}$ Block, mostly composed of micritic textures \\
\hline CIC 018 & -7.1 & 0.05 & $\mathrm{CaCO}_{3}$ Block, mostly composed of micritic textures \\
\hline CIC 021 & -6.7 & 0.25 & $\mathrm{CaCO}_{3}$ Block identified as a former root fragment \\
\hline CIC 022 & -2.3 & 0.35 & $\mathrm{CaCO}_{3}$ Block \\
\hline CIC 025 & -4.5 & 0.3 & $\mathrm{CaCO}_{3}$ Block \\
\hline CIC 029 & -6.2 & 0.27 & $\mathrm{CaCO}_{3}$ Block \\
\hline CIC 030 & -5.2 & 0.3 & $\mathrm{CaCO}_{3}$ Block \\
\hline CIC 031 & -1.2 & 0.3 & $\mathrm{CaCO}_{3}$ Block \\
\hline CIC 033 & -13 & 0.5 & $\mathrm{CaCO}_{3}$ Block \\
\hline CIC 019 & -6.6 & 0 & Partially calcitized wood fragment \\
\hline CIC 034 & -12.3 & 0.6 & Partially calcitized wood fragment \\
\hline CIC 058 & -0.5 & 0.6 & Partially calcitized wood fragment \\
\hline CIC 068 & -4 & 0.2 & Partially calcitized wood fragment \\
\hline CIC 026 & -2.2 & 0 & Partial calcite pseudomorphosis on root \\
\hline CICO35 & -16.6 & 0.8 & Needle fiber calcite \\
\hline CIC 036 & -11.3 & 0.8 & Calcite cemented sandstone \\
\hline CIC 037 & -12.6 & 0 & Soil sample near the trunk \\
\hline CIC 038 & -10.5 & 0.05 & Soil sample near the trunk \\
\hline CIC 039 & -14.2 & 0.1 & Soil sample near the trunk \\
\hline CIC 041 & -9.7 & 0.2 & Soil sample near the trunk \\
\hline CIC 059 & -8.9 & 0.2 & Soil sample below the hollow trunk \\
\hline CIC 060 & -8.4 & 0.3 & Soil sample below the hollow trunk \\
\hline CIC 061 & -7.9 & 0.4 & Soil sample below the hollow trunk \\
\hline CIC 062 & -8.9 & 0.5 & Soil sample below the hollow trunk \\
\hline CIC 063 & -6.5 & 0.6 & Soil sample below the hollow trunk \\
\hline CIC 064 & -7 & 0.7 & Soil sample below the hollow trunk \\
\hline CIC 065 & -6.5 & 0.8 & Soil sample below the hollow trunk \\
\hline CIC 066 & -8.7 & 0.9 & Soil sample below the hollow trunk \\
\hline CIC 080 & -8 & above ground & Calcite from vessel infilling \\
\hline CIC 081 & -8.2 & above ground & Calcite pseudomorphosis on cellulose fibers \\
\hline $\mathrm{CaOx}-\mathrm{Biga}$ & -19 & above ground & Oxalate extracted from the bark \\
\hline CaOX-Mankaré & -17.2 & above ground & Oxalate extracted from the bark \\
\hline $\mathrm{CaOX}-\mathrm{kani}$ & -19.8 & above ground & Oxalate extracted from the root \\
\hline Burnt $\mathrm{CaOx}-\mathrm{Biga}$ & -17.1 & above ground & Oxalate extracted from the bark burnt at $500^{\circ} \mathrm{C}$ \\
\hline Burnt $\mathrm{CaOx}-$ Mankaré & -14.6 & above ground & Oxalate extracted from the bark burnt at $500^{\circ} \mathrm{C}$ \\
\hline Burnt $\mathrm{CaOx}-\mathrm{Kani}$ & -18.3 & above ground & Oxalate extracted from the bark burnt at $500^{\circ} \mathrm{C}$ \\
\hline Wood6-Biga & -24 & above ground & Wood tissue Biga \\
\hline Iroko1-Machatoum & -25.2 & above ground & Wood tissue Machatoum \\
\hline Iroko2-Machatoum & -25.4 & above ground & Wood tissue Machatoum \\
\hline Iroko3-Machatoum & -26.2 & above ground & Wood tissue Machatoum \\
\hline Iroko4-Machatoum & -27 & above ground & Wood tissue Machatoum \\
\hline Iroko5-Machatoum & -27.8 & above ground & Wood tissue Machatoum \\
\hline MAS 1 & -4.4 & above ground & $\mathrm{CaCO}_{3}$ secretion from Massangam site \\
\hline MAS 4 & -4.9 & above ground & $\mathrm{CaCO}_{3}$ secretion from Massangam site \\
\hline MAS 7 & -6.3 & above ground & $\mathrm{CaCO}_{3}$ secretion from Massangam site \\
\hline MAS 8 & -6.2 & above ground & $\mathrm{CaCO}_{3}$ secretion from Massangam site \\
\hline MAS 9 & -2.3 & above ground & $\mathrm{CaCO}_{3}$ secretion from Massangam site \\
\hline MAS 141 & -9.3 & above ground & $\mathrm{CaCO}_{3}$ secretion from Mankaré site \\
\hline MAS 161 & -4.6 & above ground & $\mathrm{CaCO}_{3}$ secretion from Machatoum site \\
\hline
\end{tabular}



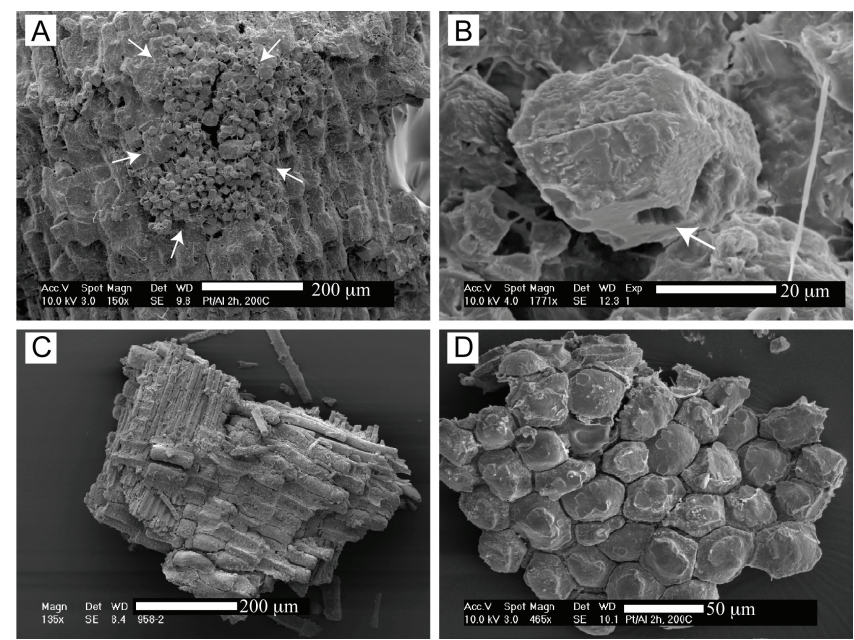

Fig. 4. (a-b) Scanning electron microscope (SEM) micrographs of a mineralized root. (a) Concentration of whewellite crystals (white arrows) due to wood tissue consumption by wood feeders (Kani site, Ivory Coast). (b) Released calcium oxalate crystal found in a decayed root, showing dissolution features (white arrow; Biga site, Ivory Coast). (c-d): SEM micrographs of calcite pseudomorphosis on wood tissues (Biga site). Calcite pseudomorphosis perfectly preserves cell and fibre details. (c) Former wood fabric, now mineralized, showing various components: thin elongated features are former cellulose fibres; the other crystals are former parenchyma cells. (d) Calcite-mineralized parenchyma cells extracted from sap bleeding from a wound on a young iroko trunk.

7.2\%o. This shift can be compared with the data of Beazley et al. (2002) who obtained a figure of $6.5 \%$ between lichen organic matter and their precipitated oxalate crystals.

\subsubsection{C isotopic signatures of carbonates}

Some specific carbonate features were separated within the mineralized wood fragments sampled below the hollow trunk:

- calcite crystal infillings from conductive vessels have a $\delta^{13} \mathrm{C}=-8.0 \%$ ( $n=1$, only from Biga site);

- calcite pseudomorphoses on cellulose fibers have a $\delta^{13} \mathrm{C}=-8.2 \%$ ( $n=1$, only from Biga site $)$;

- a block of carbonate sampled in the soil near the trunk, identified as a root, completely calcitized (Cailleau et al., 2005), has a $\delta^{13} \mathrm{C}=-6.7 \%$ ( $n=1$, only from the Biga site);

- small blocks of carbonate coming from external secretions present on trunks have a $\delta^{13} \mathrm{C}=-5.4 \pm 2.2 \%$ o $(n=7$, only from Cameroon sites).
The $\delta^{13} \mathrm{C}$ of all the various carbonate features below the hollow trunk at the Biga site has an average value of $-7.9 \pm 1.0 \%$ o $(n=8)$. At the Biga site in the profile near the trunk ( $0.5 \mathrm{~m}$ from the bark), only the top twenty centimetres of the bulk soil contain sufficient carbonates in order to perform carbon isotopic analyses. Four samples were analyzed. Their $\delta^{13} \mathrm{C}$ is $-12.6 \%$ o, $-14.2 \%,-10.5 \%$, and $-9.7 \%$, for the surface and the respective depths of, 0.05, 0.1, and $0.2 \mathrm{~m}($ mean $=-11.8 \pm 2.0 \%, n=4)$.

In the profile near the trunk, atypical calcite crystals are present (Cailleau et al., 2005, their Fig. 4b-d). These crystals have been reproduced in the laboratory experiments by burning iroko wood fragments. This kind of crystal is the result of the transformation of oxalate into carbonate at temperatures over $500^{\circ} \mathrm{C}$ (Johnson and Pani, 1962; Wolman and Goldring, 1962; Canti, 2003). Experiments at other temperatures (up to $600^{\circ} \mathrm{C}$ ) also produced carbonates but with different internal structures, as observed with LTSEM. Consequently, only samples prepared at $500{ }^{\circ} \mathrm{C}$ were analyzed as other experimental crystals are different from the observed natural ones. Carbonates produced by experimental burning of Biga and Mankaré extracted oxalate from barks have a $\delta^{13} \mathrm{C}$ of $-17.1 \%$ o $(n=1)$, and $-14.6 \%$ o $(n=1)$, respectively. Carbonate obtained during the same experiment but with oxalate from root fragments (Kani site) has a $\delta^{13} \mathrm{C}=-18.3 \%$ o $(n=1)$. The mean value for all these experimental carbonates is $-16.7 \pm 1.9 \%$ o $(n=3)$. It is obvious that a fractionation occurs when oxalate oxidizes into carbonate during incineration at over $500^{\circ} \mathrm{C}$. These fractionations are $-1.9 \%,-2.6 \%$, and $-1.5 \%$, for Biga, Mankaré bark, and Kani roots respectively, with a mean value equal to $-2.0 \pm 0.6 \%$ o $(n=3)$.

Carbonate blocks extracted from the soils at the Biga site have an average $\delta^{13} \mathrm{C}=-6.7 \%$ o $\pm 3.5(n=12)$, including a block identified as mineralized roots $\left(\delta^{13} \mathrm{C}=-6.7 \%\right.$ ) . The set of bulk soil samples below the hollow trunk (including carbonates) has a mean value of $\delta^{13} \mathrm{C}=-7.9 \%$ \pm 1.0 $(n=8)$. Finally, a mean of $\delta^{13} \mathrm{C}=-7.9 \pm 3.7 \%$ is obtained when all the carbonate samples $(n=33)$ from Ivory Coast are considered. Nevertheless, this average value has to be taken with caution as it is partially skewed because some phases have been sampled more than others.

\section{Discussion}

Microbial processes driving the carbonate accumulation in the soil around an iroko tree have already been studied (Braissant et al., 2004). However, except for the particular case of wounds caused to the trunk (Figs. 1b and 3c-d), there is no evidence of oxalate dissolution in the tree tissues. As a consequence, it seems that this system is unable to work only with both the oxalogenic tree and the soil oxalotrophic bacteria. So how does the system really work? Where does the transformation of oxalate into carbonate take place? To 
answer these questions, fluxes of matter are described and discussed using all observations made from the field to the microscopic scale.

\subsection{Matter fluxes}

\subsubsection{Flux of oxalate-bearing wood tissues to the soil beneath}

One of the first observed fluxes regarding the litter is the delamination of the oxalate-bearing bark (Fig. 1a) and the contemporaneous fall of leaves and broken branches. This process expresses the flux of organic matter embedding oxalate crystals. It leads to the presence of an increasing amount of calcium oxalate around the trunk. In addition, at this step, oxalic acid excretion by roots is also a possible source (not measured in this study). Indeed, oxalate flux into the soil is not limited to the input of calcium oxalate crystals through litter renewal and therefore, the latter must be considered as a part of the real oxalate flux to the soil. In acidic soils such as those studied, aluminium is often mobile and possibly in excess. It is well known that oxalate excretion from the roots to the soil is a mechanism used by roots to facilitate aluminium tolerance (Graustein et al., 1977). This additional flux certainly contributes to increase the $\mathrm{pH}$ and carbonate ion production through the oxalotrophy occurring around the rhizosphere.

\subsubsection{Role of termites}

Decaying of the organic matter allows the release of whewellite crystals in the first centimetres of the soil profile (Fig. 3e). This process mainly involves the action of termites and saprophytic fungi. The influence of termites on the biomineralization of the iroko tree is not limited to wood feeding and consequently to oxalate release. The most highly mineralized trees (hardened by calcite) are very often observed associated with traces of termite activity on the trunk. This is clearly expressed at the Mankaré and Biga sites cited in the present study where the trees had hollow trunks. A hollow trunk reflects the effect of termites and these trunks are generally highly mineralized. The soils developed below hollow trunks and around the stumps at Biga and Kani sites are full of small fragments and wood slabs due to termite activity. In other words, termite action enhances the flux of oxalate-bearing organic matter to the soil. All these oxalatebearing fragments increase the "expected" flux of calcium oxalate from the tree to the soil. Another direct consequence of wood feeding is a concomitant flux of carbonates to the soil as they are released by termites through their consumption of wood organic tissues surrounding carbonate precipitations (Fig. 1d).

\subsection{How does the complete system work?}

\subsubsection{Carbonate precipitation inside the tree}

How does the carbonate biomineralization take place inside the tree tissues? Thin section observations show that calcite biomineralization of the tree is not a consequence of an in situ oxalate consumption, i.e. in the wood tissues (Fig. 3a, b). According to Verrecchia et al. (2006), carbonate ions resulting from the oxalate oxidation are present in the aqueous soil solution. The oxalate oxidation takes place in the soil after the oxalate release from its embedding organic matter (Figs. 3e, 4a, b). This actually leads to a carbonate ion enrichment of the soil solution surrounding the oxalogenic tree. The calcitization of wood tissues is consequently induced by this soil solution (i.e., xylem sap) pumped through the roots. Only one example of oxalate consumption in wood tissue has been observed associated with some oxalate dissolution patterns (Fig. 3c): it is near a wound. It appears that some oxalotrophic bacteria can reach these oxalate crystals even if they are still embedded in wood. The calcitization front could act as a sort of a protective layer. This explains why this mineralization affects mostly the roots and the trunk base. This is the reason why lumbermen often have to cut into irokos at up to one meter from the ground. It is interesting to note that this pattern has also been observed in Populus trichocarpa (Janin and Clément, 1972). Carbonates are often observed as infillings in the conductive vessels of $M$. excelsa, which is not an unusual feature of trees as shown, for instance, by Clément and Janin (1973) in P. trichocarpa (regardless the soil type - acidic or alkaline). The presence of carbonates is even such a common feature of Phyllostylon brasiliensis that it constitutes a typical feature of the species (Richter and Dallwitz, 2000). In addition, inorganic calcium compounds (assumed to be calcium carbonate) have also been mentioned as a coating inside the conductive vessels of Fagus sylvatica (Bonsen and Walter, 1991).

The calcite pseudomorphosis on cells and fibres surrounding the conductive vessels, i.e. xylem rays, and cellulose (Fig. 4c, d) must be the result of diffusion processes of a $\mathrm{CO}_{3}^{2-}$ (and possibly $\mathrm{Ca}^{2+}$ )-enriched xylem sap through these tissues. Furthermore, when wounds are inflicted on the trunk and reach the conductive vessels, it is this sap that, when bleeding, leads to the genesis of carbonate coatings and hardened secretion (Fig. 1b). The subsequent impregnation of contiguous bark and sapwood by sap could lead to calcite pseudomorphosis on tissues illustrated by a front of calcitization (Fig. 3d) and mineralized parenchyma cells (Fig. 4d).

\subsubsection{Calcium: a key factor of this system?}

Regarding the relationship between $\mathrm{Ca}$ and oxalate, it is now well documented that increasing $\mathrm{Ca}$ content in the nutrient pool leads to an increase of Ca-oxalate concentration in the plant tissues (Franceschi and Nakata, 2005). At this step, 
calcium concentration in the soil appears to be an obvious key agent of the iroko ecosystem. Carbonate infilling of conductive vessels must be interpreted as the consequence of a solution enriched in both carbonate and calcium ions passing through the xylem. Under certain conditions, the sap saturation index with respect to calcium carbonate, increases, allowing crystals to precipitate. These supersaturated conditions can easily be reached either during hydric stress (due to the seasonality of rains or evapotranspiration) or possibly by increasing $\mathrm{Ca}$ concentration in sap due to tree regulation, in a springtime temperate climate (Glavac et al., 1990a, b). Although the present study takes place in climatically different conditions, the iroko ecosystem could present similar peaks in calcium concentration, which potentially and significantly enhances calcium carbonate precipitation.

In conclusion, the local fluxes of organic matter, as well as calcium exchanges occurring in the iroko tree ecosystem are summarized in a synthetic sketch given in Fig. 5. To complete this partial calcium cycle, it should be mentioned that calcium is mostly provided to the ecosystem by both atmospheric inputs (rain and dust) and weathering of the calcoalkaline granite substrate (Cailleau et al., 2004).

\subsubsection{An ideal scenario for the iroko biomineralization and soil carbonate accumulation}

Considering all observations made from samples at the Biga site, it is possible to establish a sequence of steps that should happen during the life of an iroko tree, steps leading to both biomineralization of the tree and accumulations of carbonate in the surrounding soil. According to the observations in thin sections, two sequences of events can be drawn, occurring in the bark and the wood tissues. Oxalatization is the first step recorded in the bark and wood tissues and probably at the same time, wounding can occur. As the iroko tree grows, the organic matter flux to the soil forms the litter. An oxalate pool is therefore constituted on the ground through the tree organic matter flux. Under the action of soil wood rotting agents (mainly termites, fungi, and bacteria), a significant release of oxalate crystals starts building a soil pool of "available" oxalate. At this time, oxalate consumption by oxalotrophic bacteria can begin. The next process occurring in this sequence is represented by both the silicification and calcitization only present in the bark and the wood, respectively. There is no evidence to distinguish if one of these two mineralizing phases occurs before the other. Consequently, they are considered contemporaneous. Although silicification has not been intensively investigated, it seems that the vascular system (especially phloem rays) plays an important role in it. Concerning the calcitization, carbonate and calcium ions present in the soil solution as end products of the oxalatecarbonate pathway are possibly pumped through the roots. In certain conditions, carbonate precipitation can occur both as infillings in conductive vessels and as calcite pseudomor-

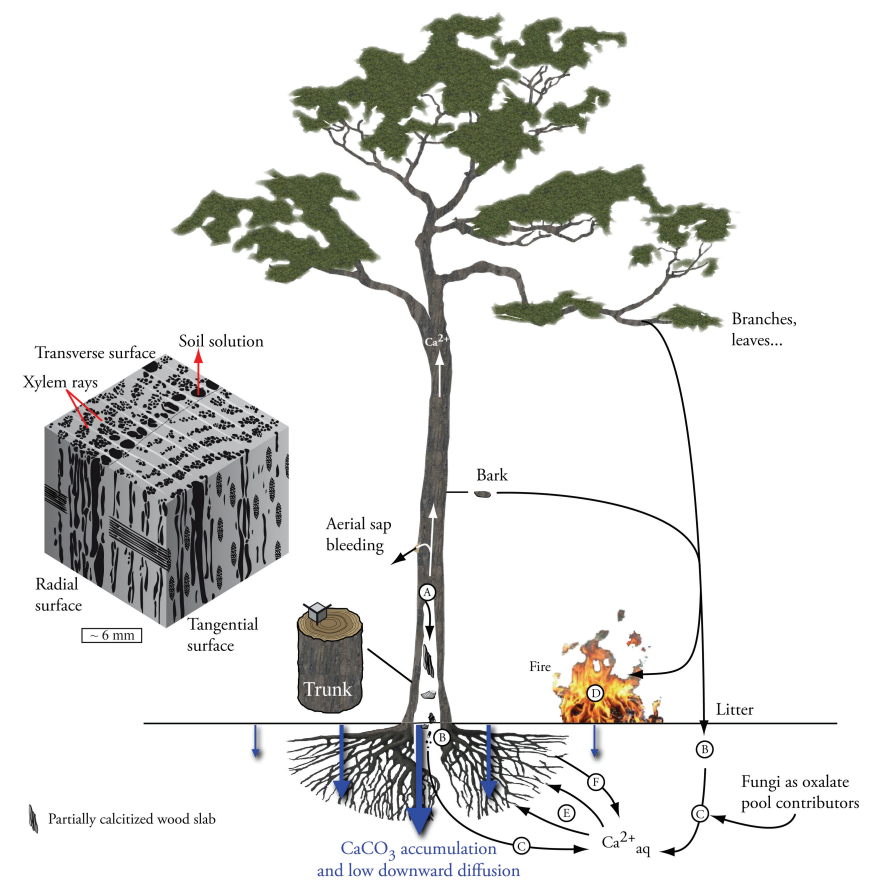

Fig. 5. Sketch showing the agents and the processes driving the iroko ecosystem. This sketch emphasizes the cycling of calcium, which is an important factor for oxalogenesis and carbonate precipitation. (a) breakdown of wood mainly related to termites and fungi; (b) final wood decay leading to oxalate crystal release; (c) oxalate crystal oxidation by soil bacteria; (d) transformation of Caoxalate into Ca-carbonate during wood combustion; (e) soil solution pumped through roots; (f) root exudation. On the left handside of the sketch, a close-up of the wood structure is given to illustrate the different xylem planes.

phoses on organic tissues by diffusion from the vascular system to adjacent tissues.

This sequence of events based on field and petrographic observations is summarized in a synthetic sketch given in Fig. 6. Additionally, as the system works continuously, the local soil $\mathrm{pH}$ gradually rises with time (soil $\mathrm{pH}$ is initially acidic in the original Ferralsol; Cailleau et al., 2005) and reaches the stability $\mathrm{pH}$ for calcite (8.4). It is then possible for calcium carbonate to precipitate inside the soil.

\subsection{Carbon isotope signatures in the iroko system}

\subsubsection{The ${ }^{13} \mathrm{C}$ fractionation through the oxalate-carbonate system}

The role of fire - The $\delta^{13} \mathrm{C}$ measured on carbonates (preconcentrated from the bulk soil under binocular microscope) from the top twenty centimetres of the profile close to the trunk are clearly lower (the lowest is $-14.2 \%$ o) than the average carbonate signature with a difference ranging from 1.8 to $6.4 \%$ (Fig. 7). Evidences of fire have been found (Cailleau et al., 2005) and are attested to by the presence of charcoal 


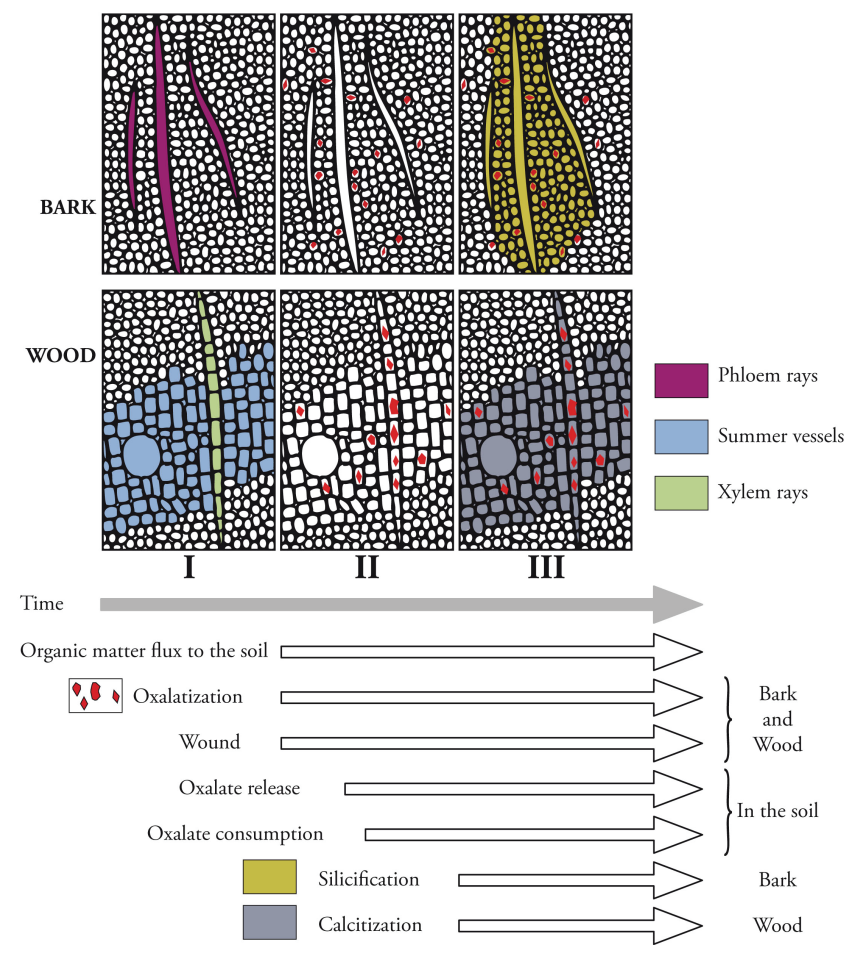

Fig. 6. Temporal occurrence of major events often observed related to the iroko oxalate-carbonate pathway. Three steps can be distinguished: Step I: "initial" state before any noticeable event happening to the seedling. Step II: Oxalatization is the first step observed related to both photosynthetic activity and concomitant organic matter flux to the soil. Whewellite is synthesized in the bark and the wood tissues. If wounds occur on the trunk, oxalotrophic bacteria contamination can initiate oxalate consumption. However, this process seems minor and the process becomes really efficient only after the release of a large amount of oxalate crystals into the soil. This last step requires an important flux of Ca-oxalate-bearing organic matter. At this stage, the process can be enhanced through termite feeding and saprophytic fungi. In the soil, oxidation of calcium oxalate by soil oxalotrophic bacteria starts and leads to the release of carbonate ions. Step III: these ions, present in the soil parent solution (i.e. as DIC), are pumped through the roots and can locally precipitate as calcium carbonate in the wood tissues (in the vascular system, or as a calcite pseudomorphosis on neighbouring tree tissues). Silicification is interpreted as synchronous to calcitization. Nevertheless, it remains unclear if amorphous silica appears after oxalatization.

and atypical calcitic crystals resulting from the transformation of oxalate into carbonate at temperature around $500{ }^{\circ} \mathrm{C}$ (Canti, 2003). Experimental burning of oxalate extracted from iroko tree samples have produced carbonates with a $\delta^{13} \mathrm{C}=-16.7 \pm 1.9 \%$ (at Biga site the $\delta^{13} \mathrm{C}=-17.1 \%$ ). Consequently, the lower values measured in the uppermost $20 \mathrm{~cm}$ should reflect the diffusion of such carbonate-bearing ashes from oxalate combustion in the top part of the soil. In other words, a simple reworking of the ground surface on which Ca-oxalate bearing iroko tissues were burnt leads to ${ }^{13} \mathrm{C}$ depleted carbonates inside the upper part of the profile.
Sap and pseudomorphoses - An important variation of carbon isotope signatures of calcium carbonate is illustrated in Fig. 7. Calcite precipitations, assumed to originate from sap solution inside the tree, are fairly similar: calcite infilling the conductive vessels and calcite pseudomorphoses on wood tissues have $\delta^{13} \mathrm{C}=-8.0 \%$ and $-8.2 \%$ signatures, respectively. This supports the assumption that calcite pseudomorphosis on wood tissues could be related to sap. These features represent the direct product of the dissolved inorganic carbon (DIC) pumped through the roots, the DIC being under the influence of oxalate substrate consumption in equilibrium with the soil $\mathrm{CO}_{2}$ (i.e. before the soil solution enters the vascular system). Indeed, this DIC is depth-dependant as the DIC pumped through the root system is theoretically in equilibrium with both soil atmosphere and the rate of organic matter decay including the oxalate consumption, which occurs mostly in the upper $30 \mathrm{~cm}$ (Braissant, 2005). The iroko root system is mainly developed in the upper $30 \mathrm{~cm}$ of soils (Mensah and Jeník, 1968). The fact that the oxalotrophy mostly occurs in this soil layer undermines the importance of the influence of the oxalate substrate on the carbon isotope signature of these carbonates. This point remains unclear and further work is needed to answer this question.

Other carbonate and oxalate features - A block identified as a calcite pseudomorphosis on root tissues (Cailleau et al., 2005) has a bulk signature of $\delta^{13} \mathrm{C}=-6.7 \%$, which is significantly different from the other features. In addition, other remaining soil carbonate samples present the same variations in their signature. This likely results from additional influences, i.e. other carbonate precipitation processes in vadose environments originating, for example, from bacterial and/or fungal activity (as suggested by Cailleau et al., 2005, 2009), as well as solely physicochemical processes.

Finally, in the proposed model (Fig. 7), two unknown pools remain: (i) the carbon isotope signature of soil oxalates; this pool is probably a mixing of oxalate from the iroko tree (whewellite) and oxalate produced by saprophytic fungi (weddellite); and (ii) it has not been possible to measure the $\delta^{13} \mathrm{C}$ of the soil DIC.

\subsection{Why is the term "ecosystem-induced carbon sink" justified?}

The terrestrial carbon sink demonstrated by Cailleau et al. (2004) and described in detail in this work can be discussed in ecological terms. First, the term carbon sink is justified because the calcium sequestrating the carbon into calcium carbonate does not originate from an inherited carbonate. Secondly, this carbon sink is of interest because of its importance. A refined calculation (compared to Cailleau et al., 2004) gives a potential lack of $\mathrm{C}$ sequestration into carbonate due to deforestation throughout Africa (and concomitant disappearance of iroko trees) equal to $1.2 \times 10^{-4}$ to $2.6 \times 10^{-3} \mathrm{PgC} \mathrm{yr}^{-1}$. 


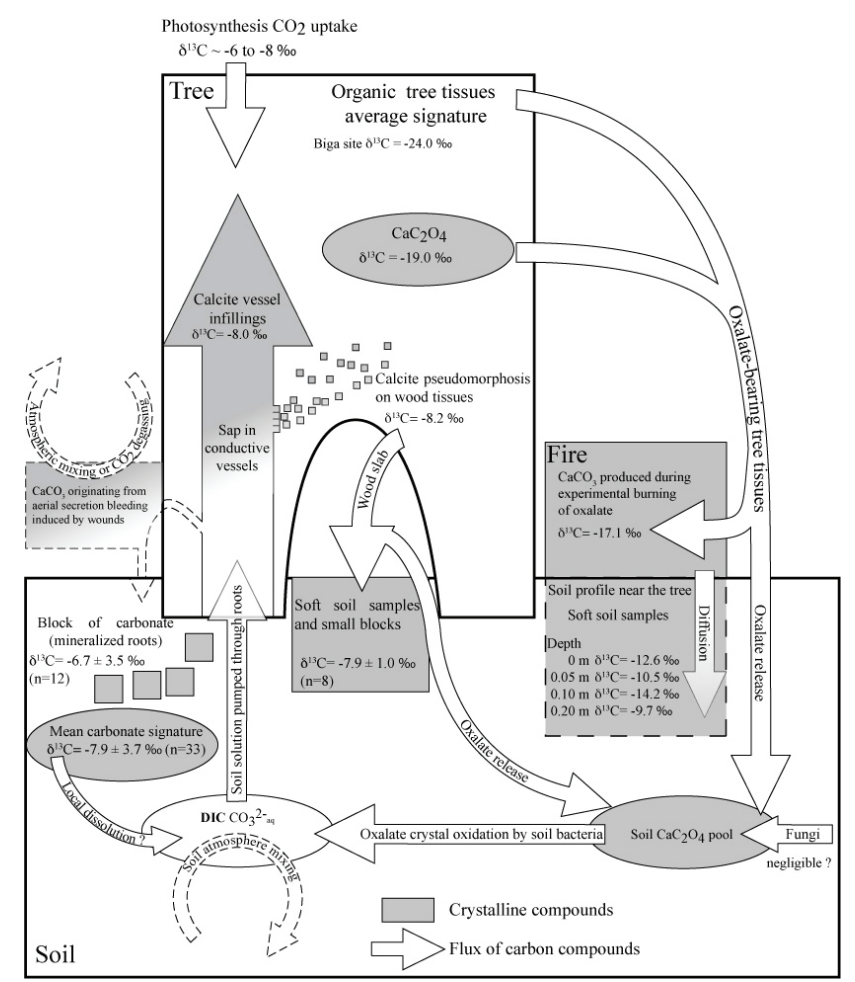

Fig. 7. Sketch of an iroko ecosystem at the Biga site (Ivory Coast) showing the various carbon fluxes and their associated mineral and organic compounds illustrated by the distribution of isotope carbon signatures. The multiple relationships between pools and agents are defined based on multiscalar observations (from field to lab). $\delta^{13} \mathrm{C}$ signature from atmospheric $\mathrm{CO}_{2}$ is given as an illustration; no measurement was performed.

Is it appropriate to use the term "ecosystem" for the iroko system? The definition of an ecosystem is historically attributed to both to Tansley (1935) and Lindeman (1942). Tansley (1935) defines an ecosystem as a system spatially limited, regardless its size, and based on an arbitrary criteria in which "objects", i.e. organisms as well as physical parameters, interact together. An ecosystem is also defined by the exchanges and interactions between organic and inorganic substances, as well as fluxes of matter and energy. In addition, there are some inputs and outputs from this entity as well.

In the case of the iroko system, the foliar crown/root system is used to limit the ecosystem. It is constituted by different trophic levels from autotrophs to heterotrophs. Synthesis, transformation, and degradation of organic matter, or more precisely carbon and calcium translocation inside and through the delimited system, represent the fluxes of matter and energy. Consequently, this carbon sink, driven by the oxalate carbonate pathway taking place around an iroko tree, constitutes a true ecosystem as defined by ecological theory.

\section{Conclusions}

The iroko biomineralisation and its related soil carbonate accumulations are known to be abundant and frequent in the intertropical African belt. These bio-induced carbonates act as a carbon sink when the calcium is not originating from previous carbonate rocks. The processes involved in the "iroko system" as well as the prerequisite actors have been documented. The processes leading to carbonate precipitation are due to the symbiosis between an oxalogenic tree, the presence of a guild of organisms able to decay the organic matrix in which the oxalate crystals are embedded, and finally, soil oxalotrophic bacteria. This system can be defined as a "carbon sink induced by an ecosystem" because the iroko and associated features fulfill all the conditions required by the definition of an ecosystem: spatially limited, presence of outputs and inputs of energy and matter, fluxes between compartments, and agents through trophic webs.

A complete functional model of this ecosystem is proposed, demonstrating that it acts as a carbon sink. The carbon and calcium pathways described in this study emphasize the carbon trapping property of the iroko ecosystem. The process of oxalate accumulation in plant tissues is not limited to the iroko tree, but rather is widespread in many groups of plants. Consequently, this study clearly points out a new important process of tropical soil carbon dynamics.

The functional model is based on field observations, petrographical investigations, and geochemical isotopic data, describing how the system works through its various pathways of carbon and calcium. Moreover, a diagenetic sequence, illustrating the temporal succession of processes taking place in the soil, as well as inside the tree, gives a picture of the complex relationships between the different players in time and space. In other words, this study demonstrates the way in which biomineralization processes in a tropical terrestrial ecosystem can lead to a carbon sink.

The African iroko ecosystem provides insight into the role of terrestrial ecosystems, which can act as a long-term carbon sink and could contribute to better understand some of the gaps in carbon budgets. Indeed, the iroko ecosystem reveals long-term carbonate deposition in soils where they are not otherwise expected.

Looking one step further, this study also emphasizes the fact that acidic African soils, known to be intrinsically nutrient poor, could locally undergo a superimposed pedogenesis associated with the oxalate-carbonate pathway. Consequently, the drastic alkalinisation caused by this process could increase the soil quality. Nevertheless, this assumption still needs to be tested. 
Acknowledgements. The authors wish to thank the CSRS (Swiss Science Research Centre, Abidjan, Ivory Coast), Mr. E. Bomisso, Université de Cocody, Abidjan, Ivory Coast, and Mr. J. M. Gargouille and Société d'Exploitation Forestière du Noun, Massangam, Cameroon. Sample preparations, ${ }^{14} \mathrm{C}$ dating and organic matter carbon isotope signature were performed at the Institute of Physics, University of Bern. Many thanks to M. André Villard who prepared all the thin sections used in this study, Thierry Adatte for XRD analysis, and Massoud Dadras for his help during electron microscopy imaging. Many thanks to K. Verrecchia for her help improving the manuscript and suggesting the title. This work has been supported by the Swiss National Science Foundation, grants no 2153-065174, 205320-101564, and K-23K1-118130, and partly funded by the EC FP7 CO2SolStock research consortium. We kindly acknowledge Alexander Brasier, three anonymous reviewers, and Steven Bouillon for their very helpful improvement to the first version of this manuscript.

Edited by: S. Bouillon

\section{References}

Beazley, M. J., Rickman, R. D., Ingram, D. K. Boutton, T. W., and Russ, J.: Natural abundances of carbon isotopes $\left({ }^{14} \mathrm{C},{ }^{13} \mathrm{C}\right)$ in lichens and calcium oxalate pruina: implications for archaeological and paleoenvironmental studies: Radiocarbon, 44, 675-683, 2002.

Bonsen, K. J. M. and Walter, M.: Calcium layers in xylem vessels, IAWA Bulletin, new series, 12, 1, 67-69, 1991.

Braissant, O.: Bacterial carbonatogenesis related to the oxalate carbonate biogeochemical cycle, Unpublished $\mathrm{PhD}$ thesis, University of Neuchâtel, Switzerland, 2005.

Braissant, O., Aragno, M., and Verrecchia, E. P.: Is the contribution of bacteria to terrestrial carbon budget greatly underestimated?, Naturwissenschaften, 89, 366-370, 2002.

Braissant, O., Cailleau, G., Aragno, M., and Verrecchia, E. P.: Biologically induced mineralization in the iroko Milicia excelsa (Moraceae): its causes and consequences to the environment, Geobiology, 2, 59-66, 2004.

Cailleau, G., Braissant, O., and Verrecchia, E. P.: Biomineralization in Plants as a long term carbon sink, Naturwissenschaften, 91, 191-194, 2004.

Cailleau, G., Braissant, O., Dupraz, C., Aragno, M., and Verrecchia, E. P.: Biologically induced accumulations of $\mathrm{CaCO}_{3}$ in orthox soils of Biga, Ivory Coast. Catena, 59, 1-17, 2005.

Cailleau, G., Verrecchia, E. P., Braissant, and O. Emmanuel, L.: The biogenic origin of needle fibre calcite, Sedimentology, 56, 1858-1875, 2009.

Campbell, W. G. and Fisher, R. C.: The composition and origin of "stone" in Iroko wood (Chlorophora excelsa, Benth. and Hook. f.). Empire Forestry Journal, 11, 244-245, 1932.

Canti, M. G.: Aspects of the chemical and microscopic characteristics of plant ashes found in archaeological soils, Catena, 54, 339-361, 2003.

Carozzi, A. V.: Recent calcite-cemented sandstone generated by the equatorial tree iroko (Chlorophora excelsa), Daloa, Ivory Coast, J. Sediment. Petrol., 37(2), 597-600, 1967.
Clausen, C. A., Kenealy, W., and Lebow, P. K.: Oxalate analysis methodology for decayed wood, Int. Biodeterior., 62, 372-375, 2008.

Cerling, T. E., Harris, J. M., MacFadden, B. J., Leakey, M. G., Quade J., Eisenmann V., and Ehleringer, J. R.: Global vegetation change through the Miocene/Pliocene boundary. Nature, 389, 153-158, 1997.

Clément, A. and Janin, G.: Étude complémentaire de la présence de cristaux de carbonate de calcium dans le bois des peupliers : existence de cinq zones fonctionnelles reconnues à partir de leurs teneurs en phosphore, Ann. Forest Sci., 30, 63-81, 1973.

Cromack, K., Sollins, P., Todd, R. L., Fogel, R., Todd, A. W., Fender, W. M., Crosley, M. E., and Crosley, D. A.: The role of oxalic acid and bicarbonate in calcium cycling by fungi and bacteria: some possible implications for soil animals, Ecol. Bull., 25, 246-252, 1977.

Diefendorf, A. F., Mueller, K. E., Wing, S. L., Koch, P. L., and Freeman, K. H.: Global patterns in leaf ${ }^{13} \mathrm{C}$ discrimination and implications for studies of past and future climate, PNAS, 107, 5738-5743, 2010.

Franceschi, V. and Horner, H. T.: Calcium oxalate crystals in plants, Bot. Rev., 46, 361-427, 1980.

Franceschi, V. R. and Nakata, P. A.: Calcium oxalate in plants: Formation and function. Annu. Rev., Plant Biol, 56, 41-71, 2005.

Gadd, G. M.: Fungal production of citric and oxalic acid: importance in metal speciation, physiology and biogeochemical processes, Adv. Microb. Physiol., 41, 47-92, 1999.

Glavac, V., Koenies, H., and Ebben U.: Seasonal variations in mineral concentrations in the trunk xylem sap of beech (Fagus sylvatica L.) in a 42-year-old beech forest stand, New Phytol., 116(1), 47-54, 1990a.

Glavac, V., Koenies, H., and Ebben U.: Seasonal variation of calcium, magnesium, potassium, and manganese contents in xylem sap of beech (Fagus sylvatica L.) in a 35-year-old limestone beech forest stand, Trees-Struct. Funct., 4(2), 75-80, 1990b.

Graustein, W. C., Cromack Jr, K., and Sollins, P.: Calcium Oxalate: Occurrence in Soils and Effect on Nutrient and Geochemical Cycles, Science, 198, 4323, 1252-1254, 1977.

Harris, C. M.: "Stone in Chlorophora excelsa B. \& H., Iroko." Empire Forestry Journal, 12, 229-238, 1933.

Hofmann, B. A. and Bernasconi, S. M.: Review of occurrences and carbon isotope geochemistry of oxalate minerals: implications for the origin and fate of oxalate in diagenetic and hydrothermal fluids, Chem. Geol., 149, 127-146, 1998.

Janin, G. and Clément, A.: Mise en évidence de cristaux de carbonate de calcium dans le bois des peupliers. Conséquences sur la répartition des ions minéraux liée à la duraminisation, Ann. Sci. Forest., 29, 67-105, 1972.

Jayasuriya, G. C. N.: The isolation and characteristics of an oxalate decomposing organism, J. Gen. Microbiol., 12, 419-428, 1955.

Johnson, F. B. and Pani. K.: Histochemical identification of calcium oxalate, Arch. Pathol., 74, 347-351, 1962.

Leidy, J.: Crystals in the bark of trees, Science, 2(43), 707-708, 1883.

Lindeman, R. L.: The trophic-dynamic aspect of ecology, Ecology, 23, 399-418, 1942.

Mensah, K. O. A. and Jeník, J.: Root system of tropical trees 2, Features of the root system of Iroko (Chlorophora excelsa Benth. et Hook.), Preslia, 40, 21-27, 1968. 
Pobeguin, T.: Les oxalates de calcium chez quelques angiospermes. Etude physicochimique. Formation. Destin. Annales des Sciences Naturelles, Botanique, 11e série, tome IV, 1-95, 1943.

Pobeguin, T.: Contribution à l'étude des carbonates de calcium. Précipitation du calcaire par les végétaux. Comparaison avec le monde animal. Annales des Sciences Naturelles, Botanique, 11e série, tome XV, 32-109, 1954.

Record, S. J.: Occurrence of calcium carbonate deposits in wood, Tropical wood, 12, 22-26, 1927.

Richter, H. G. and Dallwitz, M. J.: Commercial timbers: descriptions, illustrations, identification, and information retrieval, In English, French, German, Portuguese, and Spanish, Version: 25th June 2009, http://delta-intkey.com, 2000 onwards.

Robert, D. and Roland, J. C.: Biologie Végétale, Doin, Paris, 1989.

Schneider, A.: The probable function of calcium oxalate crystals in plants. Botanical Gazette, 32(2), 142-144, 1901.

Tansley, A. G.: The use and abuse of vegetational concepts and terms. Ecology, 16, 284-307, 1935.
Verrecchia, E. P.: Litho-diagenetic implications of the calcium oxalate-carbonate biogeochemical cycle in semiarid calcrete, Nazareth, Israel, Geomicrobiol. J., 8, 87-99, 1990.

Verrecchia, E. P., Dumont, J.-L., and Rolko, K. E.: Do fungi building limestones exist in semi-arid regions?, Naturwissenschaften, 77(12), 584-586, 1991.

Verrecchia, E. P., Braissant, O., and Cailleau, G.: The oxalatecarbonate pathway in soil carbon storage: the role of fungi and oxalotrophic bacteria, in "Fungi in the Biogeochemical Cycles", edited by: Gadd, G. M., Cambridge University Press, 2006.

Wolman, M. and Goldring, D.: Histochemical demonstration of calcium oxalate crystals, J. Histochem. Cytochem., 10, 505-506, 1962.

Walton, R. C., Kavanagh, J. P., and Heywood, B. R.: The density and protein content of calcium oxalate crystals precipitated from human urine: a tool to investigate ultrastructure and the fractional volume occupied by organic matrix, J. Struct. Biol., 143, 14-23, 2003. 